\title{
THE CORRELATION BETWEEN STUDENTS' HABIT IN LISTENING SONG AND STUDENTS' ENGLISH LISTENING SKILL
}

\author{
Nurjanah $^{1)}$, Ira Miranti ${ }^{2)}$, Nina Dwiastuty ${ }^{3)}$ \\ Program Studi Pendidikan Bahasa Inggris, \\ Fakultas Bahasa dan Seni Universitas Indraprasta PGRI \\ nurjanah3434@yahoo.com ${ }^{l)}$; ade_miranti@yahoo.com ${ }^{2}$; ninadwiastuty@yahoo.com ${ }^{3)}$
}

\begin{abstract}
The purpose of this research is to find out The Correlation between Students' Habit in Listening Song and Student's English Listening Skill. The research conducted at the senior high school of Trampil for the twelve grade students. The school is located in East Jakarta. The method used is a survey with correlational analysis. The result of the research are there is positive and significant correlation between students' habit in listening song and English listening skill. It is shown in the score of Fobserved is 39.286 and Sig is 0.000 . The score of Fobserved is more than Ftable (> 3.25), and the score of Sig is less than $0.05(<0.05)$. Based on that, we can conclude that the better of students' habit in listening song, the better students' listening skill.
\end{abstract}

Key words: Correlation, Listening Song, English Listening skill.

\begin{abstract}
Abstrak
Tujuan dari penelitian ini adalah untuk mengetahui korelasi antara kebiasaan siswa mendengarkan lagu dengan kemampuan menyimak siswa. Penelitian dilaksanakan di SMA Trampil kelas XII Jakarta Selatan. Metode yang digunakan adalah analisis korelasi. Hasil dari penelitian ini adalah terdapat korelasi yang positif dan signifikan antara kebiasaan siswa mendengarkan lagu dan kemampuan menyimak siswa, yang terlihat dalam F hitung sebesar 39.286 dengan sig 0.000. hasil dari F hitung lebih dari Ftabel (>3.25), dan nilai S kurang dari $0.05(<0.05)$. berdasarkan hal tersebut maka simpulan yang dapat ditarik adalahsemakin baik/sering siswa mendengarkan lagu maka semakin baik pula kemampuan siswa dalam menyimak bahasa Inggris.
\end{abstract}

Kata Kunci: Korelasi, Mendengarkan Lagu, Kemampuan Menyimak Bahasa Inggris

\section{INTRODUCTION}

English is important to be learnt because it is one of the most dominating language in the world. Almost country all over the world uses English as means of communication in their daily life. English is used to communicate in field of work, such as international business and education.. English is the dominant business language and it has become almost necessity for people to speak English if entering a global workforce.
So, this means that most companies require some levels of English comprehension and knowledge of the language. If you are interested in studying or working in one of the top organizations in the world, the chances are that English will be a requirement. Most movies are English, Hollywood is a powerhouse of global entertainment. So it is natural that English would become the main language for movie making. So, undoubtedly, English play a much greater role in the world. English 
is also hugely important as an international language and plays an important part even in countries. Therefore, if you have the basics of English language you can make yourself understood in nearly every corner of the world. English is the language of our international communication in all areas, such as politics, science, media or art and it is often the language of the entertainment as well as socializing.

In Indonesia, English is taught from kindergarten until university. Seeing that, the government of Indonesia is very consent toward education especially English. The minister of education decided that English is one of the subjects which are examined in National Examination either in senior high school or in junior high school. So, many educators look at a good chance to build English course. The students are not only study English in the school but they also study English in English course. The students feel not enough to study English at the school, so they need to take English course to enrich their knowledge.

English has four skills, they are: listening, speaking, reading and writing. For the first time, the human activity is listening. Such as a baby, he listens to people speaking around him. He listens to the people communicate each other. After listening well, he imitates what the people speak, like bubbling. After that, he can speak well. Then he can read and write something. Listening and reading are receptive skills because learners do not need to produce language to do these. They receive and understand it. These skills sometimes known as passive skills. Productive skills are speaking and writing. The learners use the language that they have acquired and produce a message through speech or written text that they want others to understand.
The English material for the senior high school on the national examination is listening and reading. The one way for the students in order to get a good grade in listening is get used to listen to the song. When they listen to the song, they will know either new vocabulary or pronunciation. The advantages of listening to the song often, they not only get new vocabulary and pronunciation but they also get relax. Sometimes, our feeling become happy or sad when we are listening to the song. It depends on what song they heard. In this era (high technology) we don't feel hard anymore to listen to the song. We can listen to the song by using hand phone, because it is very useful and portable. By using hand phone, we can listen to song everywhere without limited space and time.

\section{The definition of listening skill}

There are several definitions of listening. According to Helgesen, 2003:24 in (Helgesen and Steven Brown, 2007:3) "Listening is an active, purposeful processing of making sense of what we hear" Meanwhile Rost, 2002 : 279 in (Helgesen and Steven Brown, 2007:3) says " (Listening is the) " mental process of constructing meaning from spoken input". Then Richards and Schmidt, 2002 : 313 in (Helgesen and Steven Brown, 2007:3) also say "Listening comprehension (is) the process of understanding speech in a first or second language. The study of listening comprehension in second language learning focuses on the role of individual linguistic units (e.g.,phonemes, words, grammatical structures) as well as the role of the listener's expectations, the situation and context, background knowledge and topic". Then according to Rubin, 1995 : 7 in in (Helgesen and Steven Brown, 2007:3)" $\{\mathrm{L}\}$ istening is conceived of as an active process in which listeners 
select and interpret information which comes from auditory and visual clues in order to define what is going on and what the speakers are trying to express"

\section{Basic types of listening}

As with all effective tests, designing appropriate assessment tasks in listening begins with the specification of objectives, of criteria. Those objectives may be classified in terms of several types of listening performance. Think about what you do when you listen. Literally in nanoseconds, the following processes flash through your brain:

1. You recognize speech sound and hold a temporary "imprint "of them in short-term memory.

2. You simultaneously determine the type of speech even (monologue, interpersonal dialogue, transactional dialogue) that is being processed and attend to its context (who the speaker is, location purpose) and the content of the message.

3. You use (bottom-up) linguistic decoding skill and/or (top-down) background schemata to bring a plausible interpretation to the message, and assign a literal and intended meaning to the utterance.

4. In most cases (except for repetition tasks, which involve short-term memory only), you delete the exact linguistics form in which the message was originally received in favor of conceptually retaining important or relevant information in long-term memory.

Each of these stages represents a potential assessment objective:

1. Comprehending of surface structure elements such as phonemes, words, intonation, or grammatical category.

2. Understanding of pragmatic context.

3. Determining meaning of auditory input.
4. Developing the gist, a global or comprehensive understanding.

From these stages we can derive four commonly identified types of listening performance, each of which comprises a category within which to consider assessment tasks and procedures.

1. Intensive. Listening for perception of the components (phonemes, words, intonation, discourse marker, etc.) of a larger stretch of language.

2. Responsive. Listening to a relatively short stretch of language ( a greeting ,question, command, comprehension check, etc.) in order to make an equally short response.

3. Selective. Processing stretches of discourse such as short monologues for several minutes in order to "scan" for certain information. The purpose of such performance is not necessarily to look for global or general meanings, but to be able to comprehend designated information in a context of longer stretches of spoken language (such as classroom directions from a teacher, TV, or radio news items, or stories). Assessment tasks in selective listening could ask students, for example, to listen for names, numbers, a grammatical category, directions ( in a map exercise ), or certain facts and events.

4. Extensive. Listening to develop a top-down, global understanding of spoken language. Extensive performance ranges from listening to lengthy lectures to listening to a conversation and deriving a comprehensive message or purpose. Listening for the gist, for the main idea, and making inferences are all part of extensive listening.( Brown, 2004:120) 


\section{The sound of music}

Music is a powerful stimulus for student engagement precisely because it speak to our emotion while still allowing us to use our brains to analyze it and its effects if we so wish. A piece of music can change the atmosphere in a classroom or prepare students for a new activity. It can amuse and entertain, and it can make a satisfactory connection between the world of leisure and the world of learning in the classroom. Some teachers, example, like to put music on in the background when their students are working on a reading or language task or when are involved in pair work or group work. We should allow them to say what they think of the music we then play since the whole point of playing music in the first place is make students feel happy and relaxed.

We can get them to listen to music which describes people and say what kind of people they are. They can write stories based on the mood of the music they hear, or listen to more than one piece of music and discuss with each other what mood each piece describes, what' color' it is, where they would like to hear it and who with.

Even those who are skeptical about their ability to respond to music often end up-being convinced despite themselves. One of the most useful kinds of text for students to work with is song lyrics, especially where the song question is one which the students are very keen on.

There are two ways of dealing with this problem: the first is to have students bring their own favorite songs to class. If they do this, however, the teacher may want to have time (a day or two) to listen to the song and try to understand the lyrics. Some of the songs may deal with issues and language which the teacher is not keen to work with. Another solution is to use older songs, and to ask students whether they think they still have meritwhether they like them, despite their antiquity. Teachers can then choose songs which they like or which are appropriate in terms of topic and subject matter, and which they themselves think pass the test of time. Harmer, ....:320)

Here are a few possible tasks that don't require a lot at preparation time but can get at higher level processing. (Helgesen and Steven Brown, 2007:135).

1. Listen to the song (with or without seeing the words). Draw a picture based on your image of the song. Explain your picture to a partner.

2. Dictate about 10-15 key words from the song. Have students write each on a small piece of paper. Then they listen and put the words in order.

3. Make copies of the lyrics. Cut them into strips (each with one or two lines). Students read the strips and try to put them in order. Then they listen and check or change the order. (If the song tells a story, you can just cut the verses apart.)

4. Listen to a song that tells a story. With a partner, decide what happens next or what happened before. Tell your story to another group.

5. Write five or more events from a song that tells a story on the board. Listen. Put the events in order.

6. Listen with the lyrics. Talk about the meaning. Then sing.

\section{RESEARCH METHOD}

The research conducted at the senior high school of Trampil for the twelve grade students. The school is located in East Jakarta. These students are chosen because (1) some of the student has minimal score; (2) the students come from different ability in English; (3) the students come from different social culture and (4) they are 
from multi ethnics. English may be categorized as the difficult ones. This study emphasizes on the correlation between students' habit in listening song and English listening skill. It means there are one independent variables and one dependent variable; variable $\mathrm{X}$ as the independent variables (students' habit in listening song) which has interconnected and influenced the variable $\mathrm{Y}$ as the dependent variable (English listening skill). The method used is a survey with correlational analysis. In order to obtain for students' habit in listening songand English listening skill variables are by asking respondents to answer the questions given by the researcher. The respondents' answers are scored based on the existing score rule. To collect the data, the used instruments of the research are one questionnaire and data from students' mid-test score. The questionnaire is used for measuring student's habit in listening song. Meanwhile, the data test is used for students' English listening skill. The instrument test was carried out for the same population member, but they do not include a sample member, where in this research, there are only 20 students. A test type was carried out only for validity test of question item and questions of reliability test.

\section{FINDINGS AND DISCUSSION}

The purpose of this research is to find out The Correlation between Students' Habit in Listening Song and Student's English Listening Skill. From the descriptive data, after the correlation analysis which has been carried out, it is obtained that the correlation coefficient of 0.713 and the coefficient determination of $50.8 \%$. After the test carried out by SPSS programed, it was proved that the correlation coefficient was significant. It means that there is correlation between independent variable of $\mathrm{X}$ (Students' Habit in Listening Song) and dependent variable Y (English Listening Skill).

While from the regression analysis, it was obtained the equation of the regression line $\mathrm{Y}^{\wedge}=0.652+1.222 \mathrm{X}$. The constant score $=0.652$ shows that with the lowest Students' Habit in Listening Song, it was difficult for students to obtain a good English Listening Skill score, while the score of coefficient regression of 1.222 shows that there correlation between independent variable X(Students' Habit in Listening Song) and dependent variable Y (English Listening Skill). Every increase of one score of Students' Habit in Listening Song, so there will be an increase of English Listening Skill score of 1.222 .

After having been tested, the regression line linearity using SPSS programed, it was obtained that the regression line is linear. From the significance test of regression coefficient also using SPSS programed, it was obtained that the regression coefficient is significant. It really means that there is a correlation between independent variable X (Students' Habit in Listening Song) and dependent variable Y (English Listening Skill).

There is positive and significant correlation between students' habit in listening song and English listening skill. It is shown in the score of $\boldsymbol{F}_{\text {observed }}$ is 39.286 and Sig is 0.000 . The score of $\boldsymbol{F}_{\text {observed }}$ is more than $\boldsymbol{F}_{\text {table }}(>3.25)$, and the score of Sig is less than $0.05(<0.05)$. Based on that, we can conclude that the better of students' habit in listening song, the better students' listening skill.

\section{CONCLUSION}

Habit in listening song has a positive and significant correlation to 
students' listening skill. It is therefore, the researcher suggests that all teachers should encourage their students to practice listening. By giving great motivation to students to read will affect their language skills. And, the researcher also suggest to all students to practice listening every day. They can listen everything they like because it will give them more information or new knowledge. By having high listening habit, students will be easier to understand and grasp information from what they listen. And of course, it will make the easier to understand about certain topics because they have already known it before. So, they will have more confidence in giving information and sharing their ideas. The result of the research must be further evaluated and assessed. A further or specific research should be taken into consideration. In addition, this can be a reference to other researchers for the next research.

\section{REFERENCE}

Brown, H. D, (2004), Language Assessment Principles and Classroom Practice, Pearson Education.Inc

Harmer, J. (2007), The Practice of English Language Teaching, Pearson Education Limited

Helgesen, M. and Steven B. (2007), Practical English Language Teaching, The McGraw-Hill Companies, Inc. 